\title{
送水システムの性能分析および最適運用計画*
}

\author{
横山良平*1, 鮫島 正一*2, 伊東弘一*3
}

\section{Performance Analysis and Optimal Operational Planning of Water Supply Systems}

\author{
Ryohei YOKOYAMA*4, Shoichi SAMESHIMA and Koichi ITO \\ ${ }^{* 4}$ Department of Mechanical Engineering, Osaka Prefecture University, \\ 1-1 Gakuen-cho, Naka-ku, Sakai-shi, Osaka, 599-8531 Japan
}

\begin{abstract}
From the viewpoints of energy and cost savings, it is important to rationally operate water supply systems composed of pumps, piping, and reservoirs. However, it is very difficult, because nonlinear performance characteristics of pumps and piping, discrete performance characteristics due to the combination for on/off status of pumps, and daily operational strategies of reservoirs must be considered. In this paper, a two-stage approach to the performance analysis and optimal operational planning of a water supply system is proposed. At the first stage, the performance characteristics of pumps and piping are analyzed by the Newton-Raphson method, and are optimized with respect to the combination for on/off status and revolution speed ratios of pumps by the enumeration and nonlinear programming methods, respectively. At the second stage, the daily operational strategy of the system is optimized with respect to the storage level of a reservoir by the dynamic programming method. A case study is conducted to show the effectiveness of this approach.
\end{abstract}

Key Words: Systems Engineering, Water Supply Systems, Performance Analysis, Optimal Operation, Energy Saving, Cost Saving, Dynamic Programming

\section{1. 緒言}

近年，各種のエネルギー供給システムにおいて，省 エネルギーおよび省コスト化が強く求められるように なっている。.上水道の送水システムにおいても同様で あり，インバー夕技術の発達とともに可変速ポンプが 採用されるようになり，設備の面から省エネルギーお よび省コスト化が進展している。それに加えて，シス テムの設計および運用を合理的に行うことによって， さらに省エネルギーおよび省コスト化が達成されるも のと期待される.

本研究では, 送水システムが設置された後に, 省エ ネルギーおよび省コスト化を目的とした運用計画の最 適化について検討する。そのための課題として，次の

* 原稿受付 2005 年 12 月 8 日。

*1 正員, 大阪府立大学大学院工学研究科(䡤599-8531 堺市中 区学園町 1-1).

*2 (株) 明電舎環境・社会事業部 (ङ 103-8515 東京都中央区日 本橋箱崎町 36-2)

*3 正員, フェロー, 早稲田大学理工学術院総合研究所(画 169 8555 東京都新宿区大久保 3-4-1).

E-mail : yokoyama@ese.me.osakafu-u.ac.jp
ような項目が挙げられる。

(1) システムの主要な構成要素であるポンプおよび 配管の性能特性として, 流量と圧力の間の非線形 関係を考慮する必要がある。

（2）複数のポンプを含むシステムにおいては，運 転・停止に関する運用方策の代替性を考慮する必 要がある。

（３）複数の可変速ポンプを含むシステムにおいては， 運転・停止だけではなく，運転の場合には回転数 に関する運用方策の代替性も考慮する必要がある。

(4) 水の安定供給のためにシステムには配水池が設

置されるが，そのため配水需要量の時間変化にお ける一つの周期を単位として運用計画を行う必要 がある。

これらの課題によって，送水システムの最適運用計画 問題は大規模であり，非線形および組合せ的性質を持 つ複雑な最適化問題として考慮する必要があり, 解の 導出が極めて困難になる。

送水システムの最適運用計画については，以前から 多くの研究が行われている.しかしながら，システム の性能特性について簡易化されたモデルが適用された 
り, 最適化の目的関数について間接的なものが採用さ れている(1) 〜 (5). そのため, 性能特性が異なる複数 のポンプを含むシステムを対象とする場合，ならびに 夜間の安価な電力を利用する場合など, 性能特性や目 的関数などの様々な条件の下での上述の課題を考慮し た最適運用計画については十分に検討されていない.

本研究では, 送水系統が最終的に一系統になり, 終 端に配水池が設置されている送水システムについて, 上述の課題を総合的に考慮しながら, 性能分析と最適 運用計画を行うための一方法を提案するとともに，一 つの適用事例によってその有効性について検討する.

\section{2. 性能分析および最適運用計画の概要}

$2 \cdot 1$ 送水システム 図1は本研究の対象とする送 水システムの機器構成を示したものである.ここでは, 複数の取水地点に設置された複数の固定速ポンプ (PC) および可変速ポンプ (PV), ならびに配管 (PP) およ び配管分岐・合流点 (JT) によって最終的に一系統に 送水するとともに, 終端に設置された一つの配水池 （RS）に水を貯え, 時間的に変化する必要な流量の水 を配水池から配水するものとする.

$2 \cdot 22$ 段階アプローチ 前述のように, 最適運用 計画問題は大規模で複雑なものとなるため, 通常の最 適化手法では, 大域的最適解を導出することが困難と なる、また，大域的最適解を導出することができない 場合には, 最適運用計画に㧍ける検討条件の変更に伴 う最適解の変化を合理的に評価できないことになる。 本研究では, 最適運用計画問題の一解法として, 図 2 に示す 2 段階アプローチを提案する。このアプローチ では, 後述のように配水池の流入出量および貯水量を 離散的にしか扱えないという制限があるが，その制限 の下で大域的最適解を導出することができる．また， その結果, 最適運用計画における検討条件の変更に伴

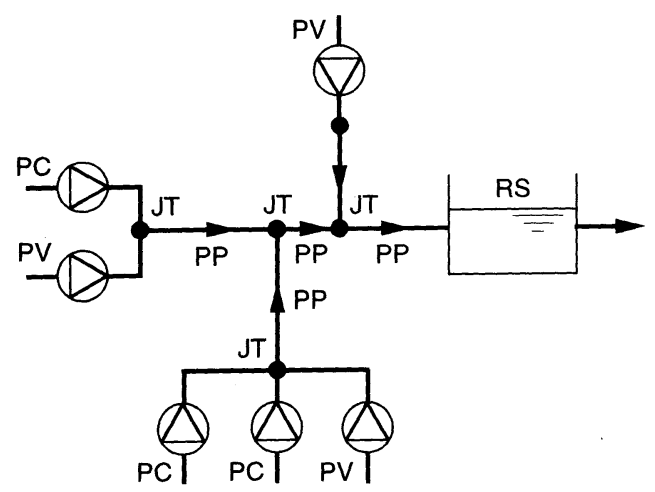

Fig. 1 Configuration of water supply system
う最適解の変化を合理的に評価することができる．特 に，第1段階でシステム性能の非線形性を考慮する必 要がある性能分析を行うことによって，第 2 段階では 後述するように動的計画法を適用し，比較的容易に大 域的最適解を導出できるようにする。

2 段階アプローチの各段階における具体的な手順は 以下の通りである.

$\mathbf{2 \cdot 2 \cdot 1}$ 第 1 段階 配水池を除外し, ポンプ, 配管, および配管分岐・合流点から構成されるシステムにつ いて, 配水池への流量を離散值を取るパラメータとし て考慮し, 各離散值に対してシステム性能を分析し, 配水池への流量と電力消費量の関係を求める。その際 に, ポンプの運転・停止および可変速ポンプの回転数 については, 代替性が存在するため, 電力消費量を最 小化するように決定する.

$\mathbf{2 \cdot 2 \cdot 2}$ 第 2 段階 配水池を含め, すべての機器か ら構成されるシステムについて，与えられた一日の配 水需要量, 第 1 段階で求められた配水池を除外したシ ステムの性能特性としての配水池への流量と最小電力 消費量の関係，および配水池の水量バランスを满足す るように，一日を周期とした最適運用計画を行う。

\section{3. 性能分析の詳細}

$3 \cdot 1$ 機器性能特性のモデル化 配水池を除外した システムを構成する各機器について, 水の流量 $G お よ$ び圧力 $p$ を変数として考慮し, 流量および圧力バラン スを定式化し，性能特性のモデル化を行う。また，ポ ンプについては, 電力消費量 $E$ を評価するための関係 式も考慮する.さらに, 可変速ポンプについては, 定 格回転数を基準とする回転数比 $R$ も変数として考慮す る.

以下に各機器について具体的に定式化を行う．各機 器に関する物理量には下付添字として機器記号を付し, 機器の入口および出口における物理量には，それぞれ 下付添字iおよび。を付加する。

3.1.1 固定速ポンプ 運転時における性能特性を

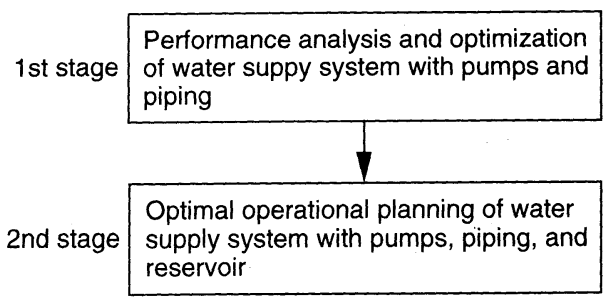

Fig. 2 Two-stage approach to performance analysis and optimal operational planning 
次式のように表す.

$$
\left.\begin{array}{l}
G_{\mathrm{PCi}}-G_{\mathrm{PCo}}=0 \\
p_{\mathrm{PCi}}-p_{\mathrm{PCo}}+f_{\mathrm{PC}}\left(G_{\mathrm{PCi}}\right)=0 \\
E_{\mathrm{PC}}=q_{\mathrm{PC}}\left(G_{\mathrm{PCi}}\right)
\end{array}\right\} .
$$

ここで, fはポンプの性能特性を表す関数であり，流量 の関数として表現する。また， $q$ は電力消費量を表す関 数であり，同様に流量の関数として表現する.

$\mathbf{3 \cdot 1 . 2}$ 可変速ポンプ＼cjkstart運転時における性能特性を 次式のように表す.

$$
\left.\begin{array}{l}
G_{\mathrm{PVi}}-G_{\mathrm{PV}_{\mathrm{o}}}=0 \\
p_{\mathrm{PVi}}-p_{\mathrm{PVo}}+g_{\mathrm{PV}}\left(G_{\mathrm{PVi}}, R_{\mathrm{PV}}\right)=0 \\
E_{\mathrm{PV}}=s_{\mathrm{PV}}\left(G_{\mathrm{PVi}}, R_{\mathrm{PV}}\right)
\end{array}\right\}
$$

ここで, $g$ はポンプの性能特性を表す関数であり，流量 および回転数比の関数として表現する。また， $s$ は電力 消費量を表す関数であり，同様に流量および回転数比 の関数として表現する.

3.1.3 配管 配管の性能特性を次式のように表す。

$$
\left.\begin{array}{l}
G_{\mathrm{PPi}}-G_{\mathrm{PPo}}=0 \\
p_{\mathrm{PPi}}-p_{\mathrm{PPo}}-h_{\mathrm{PP}}\left(G_{\mathrm{PPi}}\right)=0
\end{array}\right\}
$$

ここで, $h$ は配管の圧力損失を表す関数であり, 流量の 関数として表現する.

$\mathbf{3 \cdot 1 . 4}$ 配管分岐・合流点 $\quad M$ 本の配管から $N$ 本の 配管への分岐・合流点において，次式を考慮する.

$$
\left.\begin{array}{l}
\sum_{m=1}^{M} G_{\mathrm{JT} m \mathrm{i}}-\sum_{n=1}^{N} G_{\mathrm{JT} n \mathrm{o}}=0 \\
p_{\mathrm{JT} 1 \mathrm{i}}-p_{\mathrm{JT} m \mathrm{i}}=0 \quad(m=2,3, \cdots, M) \\
p_{\mathrm{JT} 1 \mathrm{i}}-p_{\mathrm{JT} n \mathrm{o}}=0 \quad(n=1,2, \cdots, N)
\end{array}\right\}
$$

ここでは, 配管が十分に長く, 分岐・合流点の圧力損 失が配管の圧力損失と比較して十分に小さいものと仮 定し，分岐・合流点の圧力損失を無視する.

\section{$\mathbf{3 \cdot 2}$ 接続および境界条件 上記の機器の性能特性} に加えて, 機器間の流量および圧力バランスを表す接 続条件，ならびにシステムの境界における流量および 圧力に関する境界条件を考慮する。具体的な境界条件 として, 各ポンプ入ロに扔ける圧力, ならびに配水池 入口における圧力および流量を与える。

\section{$\mathbf{3 . 3}$ 性能分析手法性能分析の手順を図 3 に示} す. $2 \cdot 2 \cdot 1$ 項で述べたように，配水池への流量の各離 散値に対してシステム性能を分析し, 配水池への流量 と最小電力消費量の関係を求める。その際に, 複数の ポンプの運転・停止によってシステム性能が不連続的 に変化するため, 列挙法によって最適なポンプの運 転・停止を決定する。すなわち, 配水池への流量を満 足するポンプの運転・停止のすべての組合せについて システム性能を分析し, 電力消費量を比較することに よってそれを最小化する運転・停止の組合せを選択す
る、また，ポンプの運転・停止の各組合せに扔いて， 運転するポンプに複数の可変速ポンプが含まれる場合 には，配水池への流量を満足する回転数比の組合せに 代替性が存在するため, 非線形計画法によって電力消 費量を最小化する回転数比の組合せを決定する。その ために，大域的準最適解を導出することができるモー ドトリミング法を適用する(6).さらに，ポンプの運 転・停止および回転数比の各組合せについて，3・1お よび $3 \cdot 2$ 節で述べた流量および圧力バランスから成る 非線形代数方程式を解き，すべての点の流量および圧 力, ならびに電力消費量を決定する。 そのために, 二 ュートン -ラフソン法を適用する。

性能分析のためのモデル化をビルディングブロック 方式によって行う ${ }^{(7)}$. すなわち, 各機器の性能特性を 表す要素モデルを独立に定義し, システムモデルを要 素モデル，接続条件，および境界条件から構成する。 これによって, システム全体のモデル化を柔軟かつ容 易に行うことができる。

\section{4. 最適運用計画の詳細}

4 -1 配水池性能特性のモデル化 配水池を含むシ ステムについて一日を周期とした最適運用計画を行う ために，3章の性能分析で除外した配水池について性 能特性のモデル化を行う。ここでは, 一日を $K$ 個のサ ンプリング時間間隔 $\Delta t$ に離散化し, 各サンプリング時 間について運用方策を決定する。このとき，配水池の 水量バランスは, 次式のように表される.

$$
\left.\begin{array}{l}
\left\{V_{\mathrm{RS}}(k)-V_{\mathrm{RS}}(k-1)\right\} / \Delta t=G_{\mathrm{RSi}}(k)-G_{\mathrm{RSo}}(k) \\
V_{\mathrm{RS}} \leq V_{\mathrm{RS}}(k) \leq \bar{V}_{\mathrm{RS}} \\
\quad(k=1,2, \cdots, K) \\
V_{\mathrm{RS}}(0)=V_{\mathrm{RS}}(K)
\end{array}\right\}
$$

ここで， $V_{\mathrm{RS}}$ は貯水量， $\bar{V}_{\mathrm{RS}}$ および $\underline{R}_{\mathrm{RS}}$ はそれぞれ $V_{\mathrm{RS}}$ の上・下限值である。また， $(k)$ は各サンプリング時間 を表す指標である。

\section{$4 \cdot 2$ 最適運用計画手法配水池を除外したシステ}

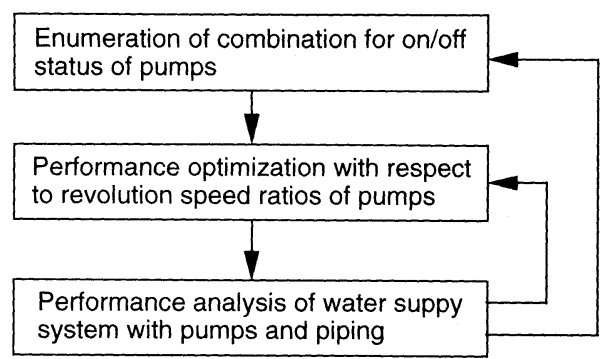

Fig. 3 Procedure for performance analysis and optimization 
ムについて，3 章の性能分析によって配水池への流 量 $G_{\mathrm{RS}}$ と最小電力消費量 $E^{*}$ の関係が次式のように求め られているものとする.

$$
E^{*}(k)=z\left(G_{\mathrm{RSi}}(k)\right)(k=1,2, \cdots, K)
$$

ここで, $z$ は最小電力消費量の配水池への流量に関する 関数である.ただし, 配水池への流量は離散值のみを 取るものと仮定し，次のように表す。

$$
\begin{aligned}
G_{\mathrm{RSi}}(k) \in\{0, \Delta G, 2 \Delta G, & \cdots, I \Delta G\} \\
& (k=1,2, \cdots, K) .
\end{aligned}
$$

ここで, $\Delta G$ は流量の離散化幅，およびIは整数である. 同様に, 配水池からの流量, すなわち配水需要量も離 散値のみを取るものと仮定し，次のように表す。

$$
\begin{aligned}
G_{\mathrm{RSo}}(k) \in\{0, \Delta G, 2 \Delta G, & \cdots, J \Delta G\} \\
(k=1,2, \cdots, K) &
\end{aligned}
$$

ここで，Jは整数である，その結果，貯水量も次のよj に離散值のみを取る。

$$
\begin{aligned}
V_{\mathrm{RS}}(k) \in\left\{\underline{V}_{\mathrm{RS}}, \cdots,(j-1) \Delta G \Delta t, j \Delta G \Delta t,(j+1) \Delta G \Delta t,\right. \\
\left.\cdots, \bar{V}_{\mathrm{RS}}\right\}(k=0,1, \cdots, K) \cdots \cdots \cdots \cdots(
\end{aligned}
$$

ここで, $j$ は整数である.

省エネルギーおよび省コストの観点から, 最小化す べき目的関数としてそれぞれ一日の電力消費量 とおよ び電力従量料金.Rを採用し, 次式のように表す.

$$
\begin{aligned}
& \mathscr{E}=\sum_{k=1}^{K} E^{*}(k) \Delta t \cdots \\
& \mathscr{R}=\sum_{k=1}^{K} r(k) E^{*}(k) \Delta t
\end{aligned}
$$

ここで，rは電力従量料金単価である。

上記の最適運用計画問題は, 図 4 に示すように, 配 水池への流量 $G_{\mathrm{RSi}}$ を決定変数, 貯水量 $V_{\mathrm{RS}}$ 状態変数, および電力消費量 $E^{*}$ あるいは電力従量料金 $r E^{*}$ 利得 とする多段決定過程として表すことができる。また， この問題は, 決定および状態変数, ならびに段を離散 的に扱う動的計画法によって解くことができる。ただ し, 式（5）に示すように, 貯水量の一日の初期值と 終端值が等しいという周期条件を考慮しながら解く必 要がある。

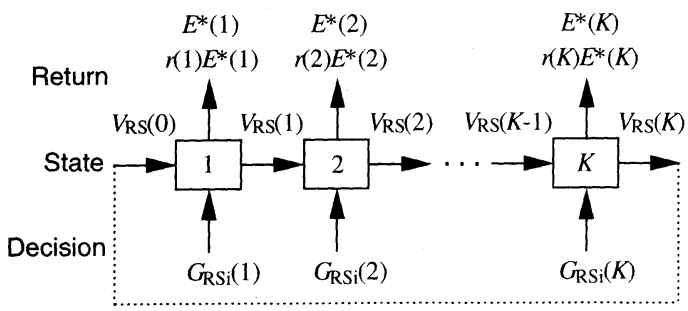

Fig. 4 Multistage decision process

\section{5. 適用事例}

$5 \cdot 1$ 対象システム適用事例として, 図 5 に示す 送水システムについて検討する。取水場として Aおよ び $\mathrm{B} の 2$ 箇所があり，Aには同種の固定速ポンプ 3 台 $\mathrm{PC} 1 \sim 3$ が設置され，Bには同種の可変速ポンプ 2 台 PV1，2が設置されている。また，2箇所の取水場か ら配管 PP1 〜 3 および配管分岐・合流点 JT1 〜 3 を通 じて，終端に設置された配水池 RSに送水を行う。さ らに，配水池から需要量に合わせて配水を行う。

\section{$5 \cdot 2$ 検討条件}

$\mathbf{5 \cdot 2 \cdot 1}$ 基本条件最適運用計画における配水池へ の流量 $G_{\mathrm{RSi}}$ の離散化幅を $\Delta G=300 \mathrm{~m}^{3} / \mathrm{h}$ とする.また， サンプリング時間数を $K=24$ ，およびサンプリング時 間間隔を $\Delta t=1 \mathrm{~h}$ とする.

$\mathbf{5 \cdot 2 \cdot 2}$ 性能特性值 固定速ポンプ PC1 3 の性能 特性および電力消費量を表す関数を，次式のようにそ れぞれ流量の二次および一次関数によって表現する。

$$
\begin{aligned}
& f_{\mathrm{PC}}\left(G_{\mathrm{PCi}}\right)=a_{\mathrm{PC}}-b_{\mathrm{PC}} G_{\mathrm{PCi}}^{2} \\
& q_{\mathrm{PC}}\left(G_{\mathrm{PCi}}\right)=c_{\mathrm{PC}}+d_{\mathrm{PC}} G_{\mathrm{PCi}}
\end{aligned}
$$

$$
\text { ここで, } a \sim d \text { は定数である. }
$$

可変速ポンプ PV1，2の性能特性および電力消費量 を表す関数を，同様にそれぞれ流量の二次および一次 関数によって表現する。たたし，流量，圧力，および 電力消費量がそれぞれ回転数の一乗，二乗，および三 乗に比例することに基づき，性能特性および電力消費 量を表す関数を，回転数比による依存性を考慮し，次 式のように表現する.

$$
\begin{aligned}
& g_{\mathrm{PV}}\left(G_{\mathrm{PVi}}, R_{\mathrm{PV}}\right)=a_{\mathrm{PV}} R_{\mathrm{PV}}^{2}-b_{\mathrm{PV}} G_{\mathrm{PV}}^{2} \ldots \ldots \\
& s_{\mathrm{PV}}\left(G_{\mathrm{PVi}}, R_{\mathrm{PV}}\right)=c_{\mathrm{PV}} R_{\mathrm{PV}}^{3}+d_{\mathrm{PV}} R_{\mathrm{PV}}^{2} G_{\mathrm{PVi}}^{2}
\end{aligned}
$$

配管の圧力損失を表す関数を, Hazen-Williamsの式 (8)に基づき，次式のように表現する。

$$
h_{\mathrm{PP}}\left(G_{\mathrm{PPi}}\right)=e_{\mathrm{PP}} G_{\mathrm{PPi}}^{1.85} L_{\mathrm{PP}} / D_{\mathrm{PP}}^{4.87}+H_{\mathrm{PP}}
$$

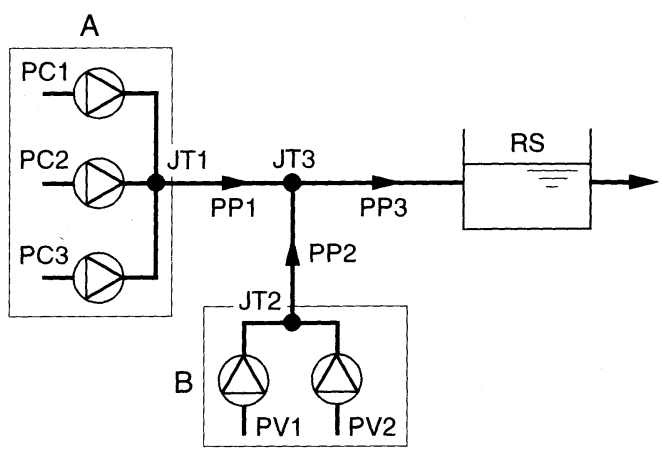

Fig. 5 Example configuration of water supply system 
ここで，Lは配管長， $D$ は配管直径， $H$ は配管出入口の 高低差による圧力ヘッド差，拈よび $e$ は定数である。

配水池については, 配水需要量の急激な変化を考慮 し, 貯水量下限値 $\underline{R}_{R S}$ として必要最小限の値を与える 必要があるが, 最適運用計画には影響を与えないため, ここでは $\underline{R}_{\mathrm{RS}}=0 \mathrm{~m}^{3}$ とする。，一方，貯水量上限值 $\bar{V}_{\mathrm{RS}}$ は パラメータとして変化させ，これが最適運用計画に与 える影響を調べる。

式（12）～（16）の各関数に含まれる定数の值を表 1 のように設定する.

$\mathbf{5 . 2 \cdot 3}$ 電力従量料金電力従量料金については, 一定および時間带別料金を採用する。なお，一日の電 力消費量を最小化する場合には, 最適運用計画が電力 従量料金に依存しないため，一定㧍よび時間带別料金 を採用する場合の解は一致する。また，一定料金を採 用する場合には, 電力従量料金が電力消費量に比例す るため, 一日の電力消費量および電力従量料金を最小 化する場合の解は一致する。したがって，ここでは一 定㧍よび時間帯別料金を採用し，一日の電力従量料金 を最小化する。電力従量料金単価を表 2 のように設定 する。

5.2.4 配水需要量 配水池からの配水需要量の時 間変化を, 図 6 に示寸ように与える。配水需要量の平

Table 1 Performance characteristic values

\begin{tabular}{c|ll}
\hline Equipment & \multicolumn{3}{|c}{ Value } \\
\hline & $a_{\mathrm{PC}}=40.0$ & $\mathrm{mAq}$ \\
$\mathrm{PC1} 3$ & $b_{\mathrm{PC}}=3.083 \times 10^{-6}$ & $\mathrm{mAq} /\left(\mathrm{m}^{3} / \mathrm{h}\right)^{2}$ \\
& $c_{\mathrm{PC}}=150.0$ & $\mathrm{~kW}$ \\
& $d_{\mathrm{PC}}=19.45 \times 10^{-3}$ & $\mathrm{~kW} /\left(\mathrm{m}^{3} / \mathrm{h}\right)$ \\
\hline & $a_{\mathrm{PV}}=50.0$ & $\mathrm{mAq}$ \\
$\mathrm{PV} 1,2$ & $b_{\mathrm{PV}}=3.472 \times 10^{-6}$ & $\mathrm{mAq} /\left(\mathrm{m}^{3} / \mathrm{h}\right)^{2}$ \\
& $c_{\mathrm{PV}}=180.0$ & $\mathrm{~kW}$ \\
& $d_{\mathrm{PV}}=16.67 \times 10^{-3}$ & $\mathrm{~kW} /\left(\mathrm{m}^{3} / \mathrm{h}\right)$ \\
\hline $\mathrm{PP} 1 \sim 3$ & $e_{\mathrm{PP}}=470.2 \times 10^{-12}$ & \\
\hline & $L_{\mathrm{PP}}=1000$ & $\mathrm{~m}$ \\
$\mathrm{PP} 1$ & $D_{\mathrm{PP}}=0.8$ & $\mathrm{~m}$ \\
& $H_{\mathrm{PP}}=0.0$ & $\mathrm{mAq}$ \\
\hline & $L_{\mathrm{PP}}=1000$ & $\mathrm{~m}$ \\
$\mathrm{PP} 2$ & $D_{\mathrm{PP}}=0.8$ & $\mathrm{~m}$ \\
& $H_{\mathrm{PP}}=0.0$ & $\mathrm{mAq}$ \\
\hline & $L_{\mathrm{PP}}=1000$ & $\mathrm{~m}$ \\
$\mathrm{PP3}$ & $D_{\mathrm{PP}}=1.2$ & $\mathrm{~m}$ \\
& $H_{\mathrm{PP}}=15.0$ & $\mathrm{mAq}$ \\
\hline
\end{tabular}

Table 2 Electricity rates

\begin{tabular}{c|c}
\hline Structure & Rate \\
\hline Flat & $r(k)=10.47$ yen/kWh $(k=1, \cdots, 24)$ \\
\hline Time-of-use & $r(k)=\left\{\begin{array}{r}6.05 \text { yen } / \mathrm{kWh}(k=1, \cdots, 8,23,24) \\
13.50 \text { yen } / \mathrm{kWh}(k=9, \cdots, 13,17, \\
14.60 \text { yen } / \mathrm{kWh}(k=14, \cdots, 16)\end{array}\right.$ \\
\hline
\end{tabular}

均值は $6.7 \times 10^{3} \mathrm{~m}^{3} / \mathrm{h}$ である.

\section{3 検討結果および考察}

$\mathbf{5 \cdot 3 \cdot 1}$ 性能分析 ポンプの運転・停止のすべての 組合せについて性能分析を行い，それによって得られ た配水池への流量と電力消費量の関係を図 7 に示す. ここで, 固定速ポンプのみを運転する場合のポンプの 運転・停止の各組合せについては, 条件として与えら れた流量を満たすことができないので，図には含まれ ていない.また，可变速ポンプの運転台数が 1 台の場 合のポンプの連転・停止の各組合せについては, 流量 および圧力バランスから成る非線形代数方程式を解い ている.さらに，可変速ポンプの運転台数が複数の場 合のポンプの運転・停止の各組合せについては，上記 の非線形代数方程式を解きながら, 可変速ポンプの回

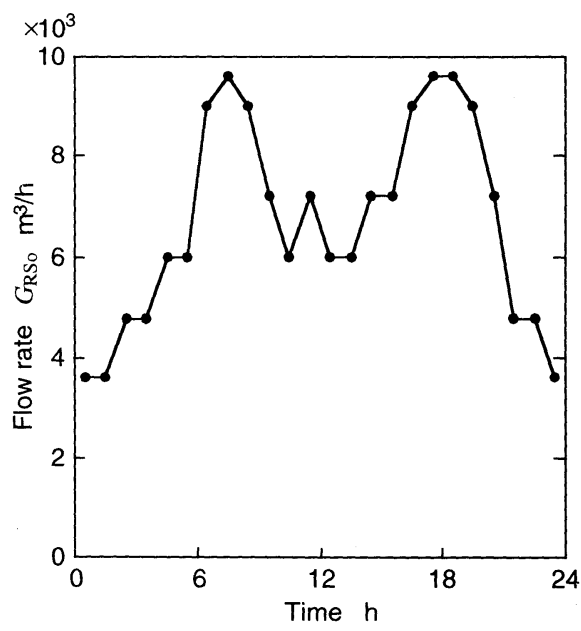

Fig. 6 Water demand

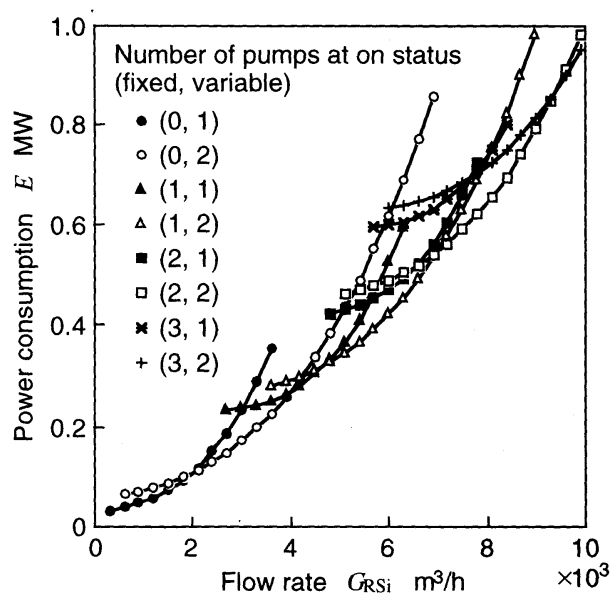

Fig. 7 Performance of pumps and piping 
転数比を変数として電力消費量の最小化を行っている. ポンプの運転・停止の各組合せに扔いて, 流量と電 力消費量の関係は放物線状に変化している。 その結果, 単位電力消費量当たりの流量の值（ここでは効率と呼 ぶ）が変化し，中流量で高く，小および大流量で低く なる，最下の曲線群が，電力消費量を最小化するポン プの運転・停止の組合せに対応する配水池への流量と 電力消費量の関係，すなわち式（6）の関係を与える. この曲線群においても, 流量と電力消費量の関係が全 体的に放物線状に変化している。また，ポンプの運 転・停止の各組合せにおいて, 効率が高くなる範囲の 曲線が選択されている。

$\mathbf{5 \cdot 3 \cdot 2}$ 一定料金下の最適運用計画 電力従量料金 として一定料金を採用した場合に，配水池の貯水量上 限值 $\bar{V}_{\mathrm{RS}}$ をパラメータとして, 一日の電力従量料金を 最小化するように最適運用計画を行い，それによって 得られた結果を図 8 に示す。（a）～（c）は，それぞ れ $\bar{V}_{\mathrm{RS}} \geq 13.8 \times 10^{3} \mathrm{~m}^{3}$ の場合のポンプの運転・停止, 配 水池への流量，および貯水量の時間変化を示す。この 結果は, 一日の電力消費量を最小化することによって 得られる結果と一致する.

配水池への流量の時間変化によれば， $\bar{V}_{\mathrm{RS}}=0 \mathrm{~m}^{3}$ の 場合には, 当然配水池への流量は配水需要量に一致す る. $\bar{V}_{\mathrm{RS}}$ の増大に伴って, 配水池への流量の時間変化 が小さくなる。すなわち，配水池を有効に利用し，一 日の配水需要量を満足する範囲内で, 効率の高い点で ポンプが運転されるようになる。例えば， $\bar{V}_{\mathrm{RS}} \geq 13.8$ $\times 10^{3} \mathrm{~m}^{3}$ の場合には， $G_{\mathrm{RS} i}=6.3 \times 10^{3}$ および $7.8 \times 10^{3}$ $\mathrm{m}^{3} / \mathrm{h}$ の効率の高い点を中心にポンプが運転されている.

貯水量の時間変化によれば，一般的には，配水需要 量が増大する直前に貯水量が増大している。，その結果， 一日に 2 回の貯水および放水のサイクルが繰り返され ており，配水池の容量が小さいことが配水池を有効に 利用することによって補われている。ただし， $\bar{V}_{\mathrm{RS}}$ が 大きい場合には，効率の高い点を中心にポンプが運転 されるために，一日に貯水抢よび放水のサイクルが 1 回だけになる傾向がある.

なお， $\bar{V}_{\mathrm{RS}}=3 \times 10^{3}$ と $6 \times 10^{3} \mathrm{~m}^{3}$ の場合における $24: 00$ (0:00) の配水池への流量および貯水量の逆転は, 最適 解の唯一性が保証されていないためと考えられる。す なわち，図6によると，23:00～2:00の配水需要量が同

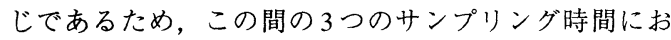
いて最適運用方策に代替性が生じるためと考えられる。 $\bar{V}_{\mathrm{RS}}=3 \times 10^{3} \mathrm{~m}^{3}$ の場合には, 配水池への流量が 23:00 24:00に増大し，0:00～2:00に減少しているが，それぞ れのサンプリング時間を変更しても目的関数の值は変
化しない。一方， $\bar{V}_{\mathrm{RS}}=6 \times 10^{3} \mathrm{~m}^{3}$ の場合には，配水池 への流量が 23:00〜 24:00に減少し，0:00〜2:00に増大 しているが，それぞれのサンプリング時間を変更して も目的関数の值は変化しない.

$\mathbf{5 \cdot 3 \cdot 3}$ 時間帯別料金下の最適運用計画 電力従量 料金として時間帯別料金を採用した場合に，配水池の

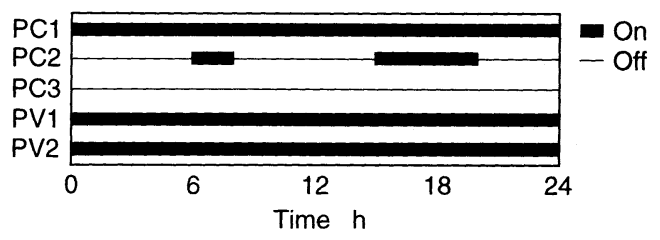

(a) On/off status of pumps $\left(\bar{V}_{R S} \geq 13.8 \times 10^{3} \mathrm{~m}^{3}\right)$

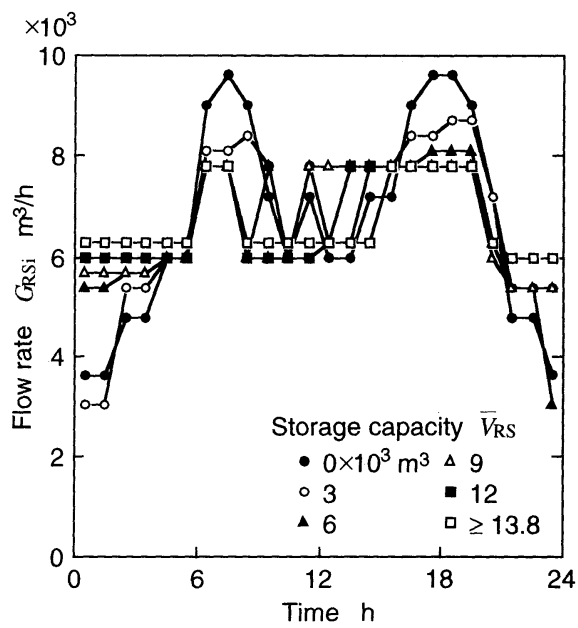

(b) Flow rate

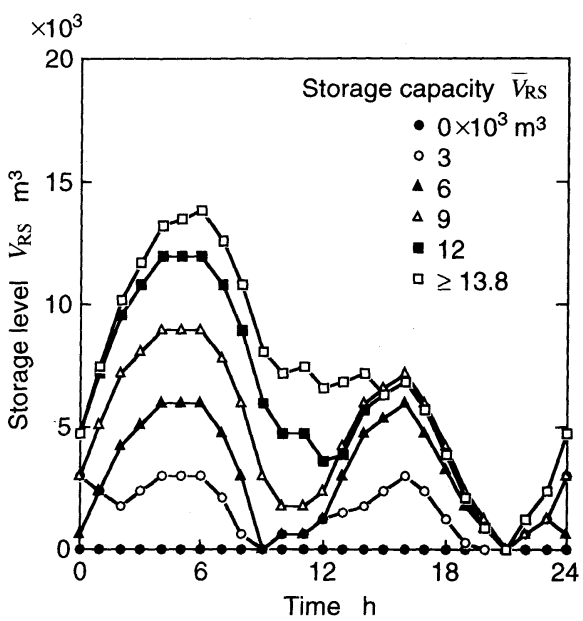

(c) Storage level

Fig. 8 Optimal operational strategy of case with flat rate 
貯水量上限值 $\vec{V}_{\mathrm{RS}}$ をパラメータとして, 一日の電力従 量料金を最小化するように最適運用計画を行い，それ によって得られた結果を図 9 に示す。（a）〜（c）は， それぞれ $\bar{V}_{\mathrm{RS}} \geq 43.2 \times 10^{3} \mathrm{~m}^{3}$ の場合のポンプの運転・停 止, 配水池への流量, および貯水量の時間変化を示す.

配水池への流量の時間変化によれば, 電力従量料金

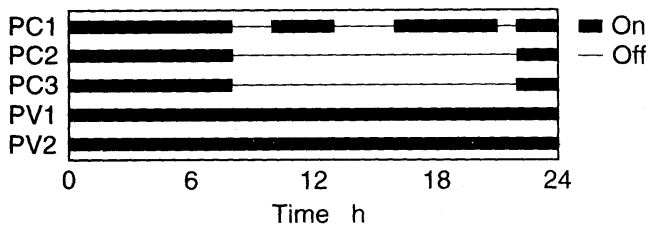

(a) On/off status of pumps $\left(\bar{V}_{\mathrm{RS}} \geq 43.2 \times 10^{3} \mathrm{~m}^{3}\right)$

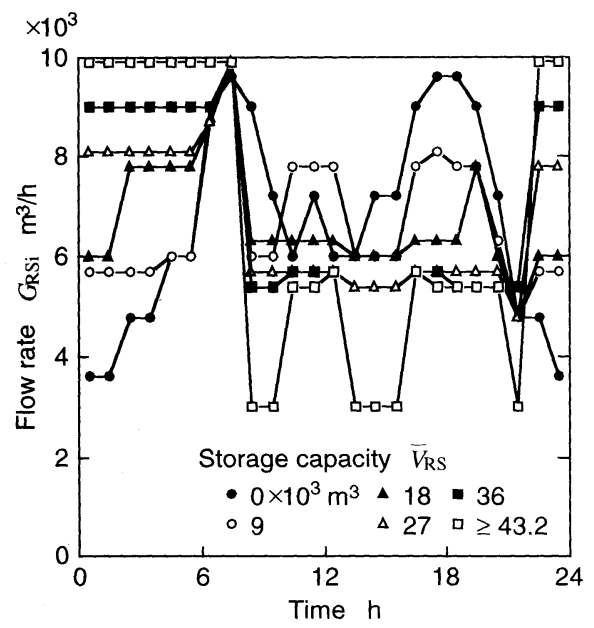

(b) Flow rate

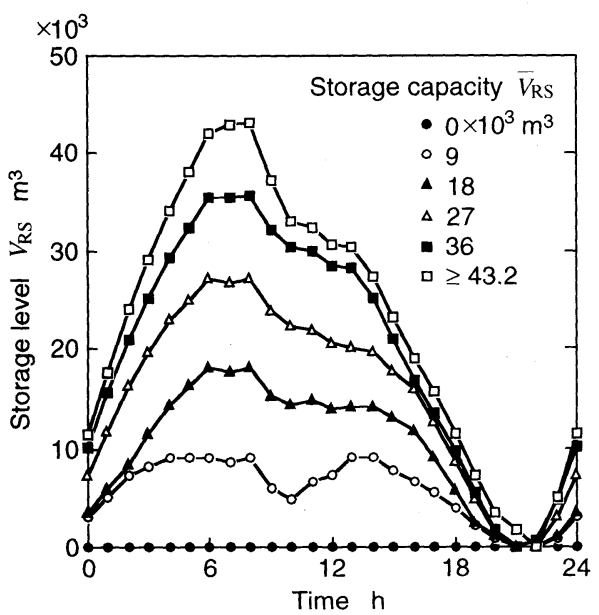

(c) Storage level

Fig. 9 Optimal operational strategy of case with time-of-use rate
が夜間に安価で，昼間に高価であるため， $\bar{V}_{\mathrm{RS}}$ の増大 に伴って配水池への流量が夜間に増大し, 昼間に減少 するようになる。例えば， $\bar{V}_{\mathrm{RS}} \geq 43.2 \times 10^{3} \mathrm{~m}^{3}$ の場合に は, 夜間に $G_{\mathrm{RSi}}=9.9 \times 10^{3} \mathrm{~m}^{3} / \mathrm{h}$ の最大流量の効率の低 い点で，昼間に $G_{\mathrm{RSi}}=3.0 \times 10^{3}$ および $5.4 \times 10^{3} \mathrm{~m}^{3} / \mathrm{h}$ の効 率の高い点を中心にポンプが運転されている。特に, 電力従量料金が高価となる時間帯には， $G_{\mathrm{RSi}}=3.0 \times 10^{3}$ $\mathrm{m}^{3} / \mathrm{h}$ の効率が高く, 電力消費量が小さくなる点でポン プが運転されている。

貯水量の時間変化によれば， $\bar{V}_{\mathrm{RS}}$ が小さい場合には, 配水池の容量が小さいことを配水池を有効に利用する ことによって補うために，一日に2 回の貯水抢よび放 水のサイクルが繰り返される傾向がある。しかしなが ら，一般的には，一日に貯水および放水のサイクルが 1 回だけになる。これは, 夜間の安価な電力従量料金 を有効に利用するために, 夜間に配水池への流量を増 大させるためである。

$\mathbf{5 \cdot 3 . 4}$ 電力消費量および電力従量料金の比較 図 10 は, 電力従量料金として一定および時間帯別料金を 採用した場合に，一日の電力従量料金の最小化によっ て得られる一日の電力消費量と貯水量上限値 $\bar{V}_{\mathrm{RS}}$ の関 係を示したものである.

一定料金を採用した場合には， $\bar{V}_{\mathrm{RS}}$ の増大に伴って 電力消費量が減少し, $\bar{V}_{\mathrm{RS}}=13.8 \times 10^{3} \mathrm{~m}^{3}$ で最小值に達 する。一方，時間帯別料金を採用した場合には，電力 消費量は最小值よりは大きいが， $18.0 \times 10^{3} \mathrm{~m}^{3}$ まで は $\bar{V}_{\mathrm{RS}}$ の増大に伴って減少する。しかしながら， $\bar{V}_{\mathrm{RS}}$ が $18.0 \times 10^{3} \mathrm{~m}^{3}$ より大きくなると，電力消費量は増大する ようになる。これは，前述のように夜間に効率の低い

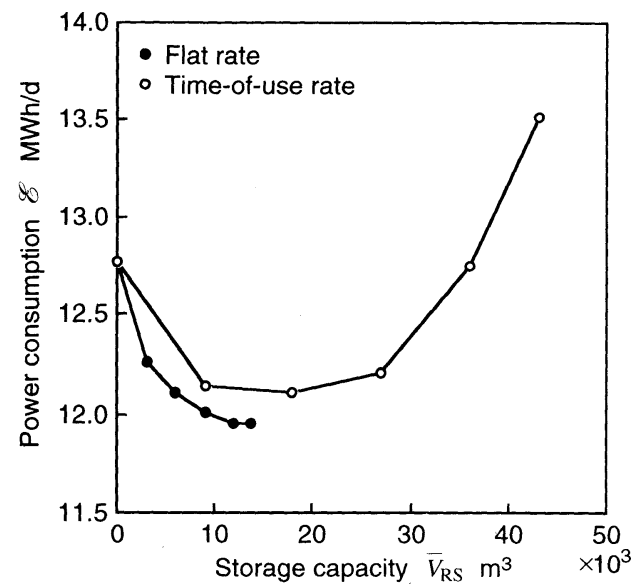

Fig. 10 Comparison of power consumption between cases with flat and time-of-use rates 


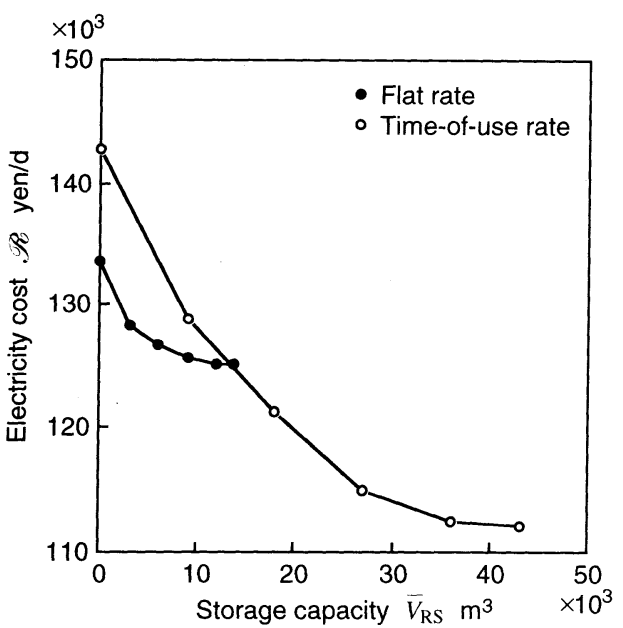

Fig. 11 Comparison of electricity cost between cases with flat and time-of-use rates

点でポンブが運転されるようになるためである。

図 11 は，図 10 に対応して，電力従量料金として一定 および時間帯別料金を採用した場合に，一日の電力従 量料金の最小化によって得られる一日の電力従量料金 と貯水量上限值 $\bar{V}_{\mathrm{RS}}$ の関係を示したものである.

一定料金を採用した場合には，電力従量料金は電力 消費量に比例するため， $\bar{V}_{\mathrm{RS}}$ の増大に伴って電力従量 料金が減少し, $\bar{V}_{\mathrm{RS}}=13.8 \times 10^{3} \mathrm{~m}^{3}$ で最小値に達する. 一方，時間帯別料金を採用した場合には， $\bar{V}_{\mathrm{RS}}$ の増大 に伴って夜間の安価な電力従量料金を有効に利用する ことができるようになり，電力従量料金は大幅に減少 する。

\section{6. 結言}

本研究では，送水系統が最終的に一系統になり，終 端に配水池が設置されている送水システムについて, ポンプおよび配管の性能特性の非線形性, 複数のポン プの運転・停止および回転数に関する運用方策の代替 性，ならびに配水池の一日の運用方策を総合的に考虑 しながら，最適運用計画を行うための一方法を提案し た。大規模で複雑な最適運用計画問題の解の導出を行 うために，2段階アプローチを提案し，配水池を除外 したシステムについて性能分析を行うとともに，その 結果に基づき配水池を含むシステムについて一日の最
適運用計画を行う方法を提示した。また，一つの適用 事例によって本方法の有効性について検討した，電力 従量料金として一定および時間帯別料金を採用した場 合に, 一日の電力従量料金を最小化する最適運用計画 を行い，配水池の容量によるポンプおよび配水池の運 用方策，ならびに電力消費量および電力従量料金の変 化の特徴を明らかにし，本方法によって合理的に運用 計画を行うことができることを示した。

なお，適用事例における性能分析については，機器 性能特性として一般的に用いられる流量および圧力バ ランスのモデルに基づいて検討した，実在する送水シ ステムの性能分析への本方法の適用，ならびに実デー 夕との比較検討については, 今後の研究課題としたい.

\section{文䵧}

(1) Hatakeyama, J., Matsumoto, K. and Taniguchi, H., Optimization of Distribution of Flow and Pressure in Water Network, Trans. IEE Japan, 98-9, C (1978), 289-296, (in Japanese).

(2) Ohsato, A., Yamaguchi, H., Sekiguchi, T., Saito, S. and Kodate, H., A Hierarchical Optimization on a Wide Water Supply System With Transport Delay, Trans. IEE Japan, 99-5, C (1979), 103-110, (in Japanese).

(3) Saito, S., Optimization of Water-Supply System and Reflections on Identification of Weighting Factors, Trans. SICE, 19-6 (1983), 472-479, (in Japanese).

(4) Kurisu, H., Nishiya, T., Tachi, N. and Adachi, H., A Dynamic Distribution Method Composed of Mathematical Programming and Heuristic Method and Its Application to Water Management, Trans. SICE, 30-2 (1994), 198207, (in Japanese).

(5) Sakamoto, Y., Kurokawa, F., Sano, M., Yamada, T., Ashiki, T. and Yuki, H., Quasi-Optimization of Water Distribution Scheduling Based on GA, Trans. IEE Japan, 120-8/9, D (2000), 987-999, (in Japanese).

(6) Yokoyama, R. and Ito, K., Modal Trimming Method for Improving Local Optima of Nonlinear Programming Problems, Trans. JSME, 69-688, C (2003), 3243-3250, (in Japanese).

(7) Yokoyama, R., Takeuchi, S. and Ito, K., Thermoeconomic Analysis and Optimization of a Gas Turbine Cogeneration Unit by a Systems Approach, Proc. ASME Turbo Expo 2005, Paper No. GT2005-68392 (2005), 1-7.

(8) Japan Society of Civil Engineers, Formulary for Hydroscience, 1999 Ver. (1999), Japan Society of Civil Engineers, (in Japanese). 